\title{
Conciliating artisanal and recreational fisheries in Anegada Bay, Argentina
}

\author{
F.M. Llompart ${ }^{\mathrm{a}, \mathrm{b}, \mathrm{c}, *}$, D.C. Colautti ${ }^{\mathrm{c}, \mathrm{d}}$, C.R.M. Baigún ${ }^{\mathrm{c}, \mathrm{e}}$ \\ a Centro Austral de Investigaciones Científicas, Bernardo Houssay 200, V9410CAB Ushuaia, Tierra del Fuego, Argentina \\ ${ }^{\mathrm{b}}$ Universidad Nacional de Tierra del Fuego (UNTDF), Onas 400, Ushuaia, Tierra del Fuego, Argentina \\ ' Consejo Nacional de Investigaciones Científicas y Técnicas (CONICET), Buenos Aires, Argentina \\ d Instituto de Limnología “Dr. Raúl A. Ringuelet", Boulevard 120 y 62, CP: 1900 - CC: 712 La Plata, Buenos Aires, Argentina \\ e Instituto de Investigación e Ingeniería Ambiental (3iA), Universidad Nacional de San Martín, Campus Miguelete, 25 de Mayo y Francia s/n (1650), Gral. \\ San Martín, Buenos Aires, Argentina
}

\section{A R T I C L E I N F O}

\section{Article history:}

Received 12 May 2016

Received in revised form 12 January 2017

Accepted 23 January 2017

Handled by George A. Rose

\section{Keywords:}

Coastal fisheries

Anegada Bay

Fisheries conflicts

Common-pool resources

Sea management

Fisheries management

\begin{abstract}
A B S T R A C T
Recreational and artisanal fisheries are common activities in Latin America often interpreted as competitors due to the use of common-pool resources in coastal areas. Conflicts between the (historical) artisanal fisheries (AF) and recreational fisheries (RF) in Anegada Bay resulted in the prohibition of the former. This study addresses key fisheries characteristics to detect the degree of spatio-temporal overlap between them considering the annual dynamic of the coastal fish assemblage and proposed management alternatives. Both fisheries exerted different fishing effort coinciding with the dynamic of the fish assemblages but partial temporal and spatial overlap where apparent especially during one month. However, both fisheries focused their catches on different target species thus greatly reducing the overlap in resource use. Moreover, the low proportion of juveniles caught, limited fishing effort using selective bottom gillnets and scarce total harvest (168 tonnes/years) for AF compared with those of RF harvest (631 tonnes/years) in Anegada Bay poorly justifies the actual prohibition. However, the vulnerability index of AF landings resulted in higher values than the RF. To resolve conflicts, a co-management including $A F, R F$ and industrial (trawl) stakeholders and non-fishing community is suggested. Because of the economic importance of fishing for local people, an efficient inter and intra-sector communications process and new fisheries guidelines are urgent for the equitable use of fisheries resources without compromising the goals of a protected area.
\end{abstract}

(c) 2017 Elsevier B.V. All rights reserved.

\section{Introduction}

Fisheries and coastal systems are intrinsically diverse, complex and dynamic (Jentoft and Chuenpagdee, 2009). Moreover, an ongoing coastal area migration is happening in many parts of the world (Pauly, 2006) which is adding pressure onto the resources, and consequently, is increasing the competition among the numerous users of these limited resources (Jentoft, 2000). The demands of new actors in coastal areas (recreational fishers, conservation organisations, scuba divers, tourist operators, among others) and the consequent diversity of usages have added a complexity to the interactions thereon. They are creating new governability chal-

\footnotetext{
* Corresponding author at: Centro Austral de Investigaciones Científicas, 200 Bernardo Houssay, V9410CAB Ushuaia, Tierra del Fuego, Argentina.

E-mail address: facundollompart@hotmail.com (F.M. Llompart).
}

lenges that are ultimately aimed towards a shared and rational use of coastal marine resources. However, in finding practical management solutions about resource sharing have proved to be very difficult, since human dimensions are involved on multiple levels, horizontally between the users and vertically between the users, managers, scientists, politicians, and the public at large (Arlinghaus, 2005).

In the last few years, there has been an international increment of concern about the roles that are played by artisanal and recreational fishing in global catches and in local economies (Coleman et al., 2004; Béné, 2006; Chuenpagdee et al., 2006; Cooke and Cowx, 2006; Teh and Sumaila, 2013). For example, the artisanal fisheries sector involves 50 million people (Berkes et al., 2001). They harvest an estimated 21 million tonnes per year in marine environments (Chuenpagdee et al., 2006) and represent a huge socio-economic relevance for many coastal populations (Allison and Ellis, 2001; 
Berkes et al., 2001; Andrew et al., 2007; Zeller et al., 2007). For the case of recreational fisheries, approximately $11.5 \%$ of the world's population is involved in capturing $12 \%$ of the total global catch (Cooke and Cowx, 2004). This produces high revenues for both developed and developing countries (Pitcher and Hollingworth, 2002). These values rearrange these fisheries into the foreground and show the need to improve our knowledge about artisanal and recreational fisheries in coastal zones, in order to secure their sustainable development (Salas et al., 2007; Chuenpagdee, 2011).

Evaluations that try to account for the conflicts between the fishery sectors and to quantify their reduction under alternative policies are still preliminary (Pitcher and Hollingworth, 2002). The understanding of conflicts is a prerequisite for the planned sustainability actions (Renae, 2006). Intra-sectoral conflicts, especially between the artisanal and recreational fisheries, may be due to several reasons, such as: i) the current increment of recreational fisher's participation rates, together with the improved accessibility to previously remote fishing areas (Arlinghaus, 2005); ii) a spatiotemporal overlap, since fishing is practised and is restricted to within a few nautical miles from the coastline, due to the seasonal nature of available resources, especially in temperate environments; iii) a mutual mistrust about fishing practices or their impacts; and iv) different views and priorities about the guidelines for the sustainable use of resources which are not based on knowledge as much as they are on one's own values and interests (Jentoft and Chuenpagdee, 2009). Besides, intra-sectoral conflicts can be more severe when two fisheries share the same target species whereas inter-sectoral conflicts with non-fishing stakeholders, governance institutions, and citizens in general, can drive up the expense of fishery management (Arlinghaus, 2005).

Recreational and artisanal fisheries are frequent coastal activities in many parts of the world, including the Latin American countries (FAO, 2012a,b; Defeo, 2014). Argentina, for instance, has an extended marine shoreline $(5000 \mathrm{~km})$ where artisanal fishing is becoming a permanent livelihood for many people (Elías et al., 2011). In Anegada Bay, in the Northern Argentinean Patagonia, artisanal fisheries have been taking place for more than 100 years. Such fisheries provided a major source of food, employment, and economic benefits to the ancient inhabitants of Anegada Bay showing a temporal increase between 1939 and 1945, due to the demands of shark-oil from the school shark [Galeorhinus galeus (Linnaeus, 1758)] and then the fishing efforts decreased (Lasta et al., 2001). Until 2007, artisanal fishing was developed by following the fishing regulations imposed by the enforcement authority (Dirección Provincial de Pesca, Provincia de Buenos Aires http://www.maa. gba.gov.ar/pesca), but after was banned.

On the other hand, in Anegada Bay, the beginnings of the recreational fisheries took place 6 decades ago, but there is evidence of an abrupt increment over the last 15 years. Previous results on recreational fisheries have shown the current relevance of this activity, in terms of attracting tourism $(39,649 \pm 9320$ people per year for the last ten years), increasing the employment demands, and the incomes that this produces (Llompart et al., 2012). Over time, however, the conflicts involved in these two fishery sectors, including the local non-fishing stakeholders, have led to a prohibition of artisanal fishing in the bay. Even though, such a decision was not based on an integral evaluation. To partially address this gap of information, the objective of this study was to obtain a comprehensive framework for both artisanal and recreational fisheries in the bay and then to analyse to what extent such activities were overlapped on a spatio-temporal basis, regarding the amount and the types of fish caught. The main reasons for the conflicts and the governance constraints are also analysed, in order to propose sustainable management alternatives to enhance the fisheries management and the fish conservation in the marine protected area of Anegada Bay.

\section{Materials and methods}

\subsection{Study area}

Anegada Bay is located along the southern coastline of the Buenos Aires Province, Argentina (Fig. 1). This zone is a protected nature area of multiple uses, being considered as part of North Patagonia. The area protects several types of coastal environments, e.g., marshes, tidal plains, and sandy beaches (Penchaszadeh et al., 2003). The bay comprises of small islands and banks that are connected by a diffuse network of channels with depths ranging from $10 \mathrm{~m}$ to $24 \mathrm{~m}$ in the main channel (Lucifora, 2003). The tidal regime is predominantly a mixed semidiurnal, with a maximum amplitude of $2.56 \mathrm{~m}$ and a minimum of $1.73 \mathrm{~m}$ (SHN, 2009). The water temperature ranges from $6.8^{\circ} \mathrm{C}$ in winter to $19.2^{\circ} \mathrm{C}$ in summer, while the salinity varies between 32.5 and 35.0 PSU (Borges, 1997, 2006). The climate is dry ( $300 \mathrm{~mm} / \mathrm{year}$ of precipitation) and the prevailing winds are from the northwest.

\subsubsection{Recreational fishery}

The main recreational fisheries (RF) take place in San Blas Bay, both from the shoreline and from boats (Fig. 1). The shore-based $\mathrm{RF}$ (SRF) are carried out along $4 \mathrm{~km}$ of the village's coastline, on a steeply sloping pebble and gravel beach, and for $4.4 \mathrm{~km}$ on a gently sloped sandy beach, located to the south of the village. For the purposes of this study, the fishing information from these two sites is presented together, as both being SRF.

For the assessment of RF, we developed a two-stage stratified sampling design. The two variables considered were the fishing places (shore-based and boat-based) and the fishing efforts over time [i.e., months and also weekdays and weekend days (Malvestuto and Knight, 1991)]. We conducted a roving-creel survey (Robson, 1991; Pollock et al., 1994; Sullivan et al., 2006) during 108 days of field work between April 2009 and April 2010 (except for May and August of 2009) and we used a semi-structured questionnaire (Sudman and Bradburn, 1982) in order to obtain information about the anglers preferences and their fishing trips. After each angler's interview, the species composition and the number and the length of fish caught were recorded and compared with minimum legal catch size and length at first maturity. The total weight was estimated from the length-weight relationships for each species in the study area (Llompart, 2011). The basic catch and effort statistics were calculated following the procedure of Pollock et al. (1994). The details about the formulas employed and the sampling design can be found in Llompart et al. (2012). For the case of the SRF, two daily instantaneous counts of the anglers were made.

Since the particular dynamics of boat-based recreational fishery (BRF) prevented the implementation of access point surveys (Pollock et al., 1994), their catch estimation was carried out in a different way. In order to get an estimated of the amount of catches, the total number of boats available to rent (between 35 and 40 ), the number of BRF anglers per year $(11,430)$, the mean duration of the fishing trip $(4 \mathrm{~h})$ and total number of fishing trip per month (2321 per season) were registered and contrasted with official records. In the landing port, the catch amount and composition (in percentages) were recorded ( $\mathrm{N}=130$ records) during all months of the 2009-2010 fishing season and validated at fillet processing plants $(\mathrm{N}=50$ samples). This information was supplemented by the records of the daily catches of one boat randomly sampled considered to be representative of the others and also supported by more than 30 BRF fishing trips in every month of the season and in at least 10 different sites within the bay. The number of daily fishing trips made by all of the boats during each month of the year was provided by the coastal guard placed in San Blas Bay. The BRF catch per unit effort (CPUE) was estimates from the total catch of species during a mean fishing trip time and then expanded to the total fishing 


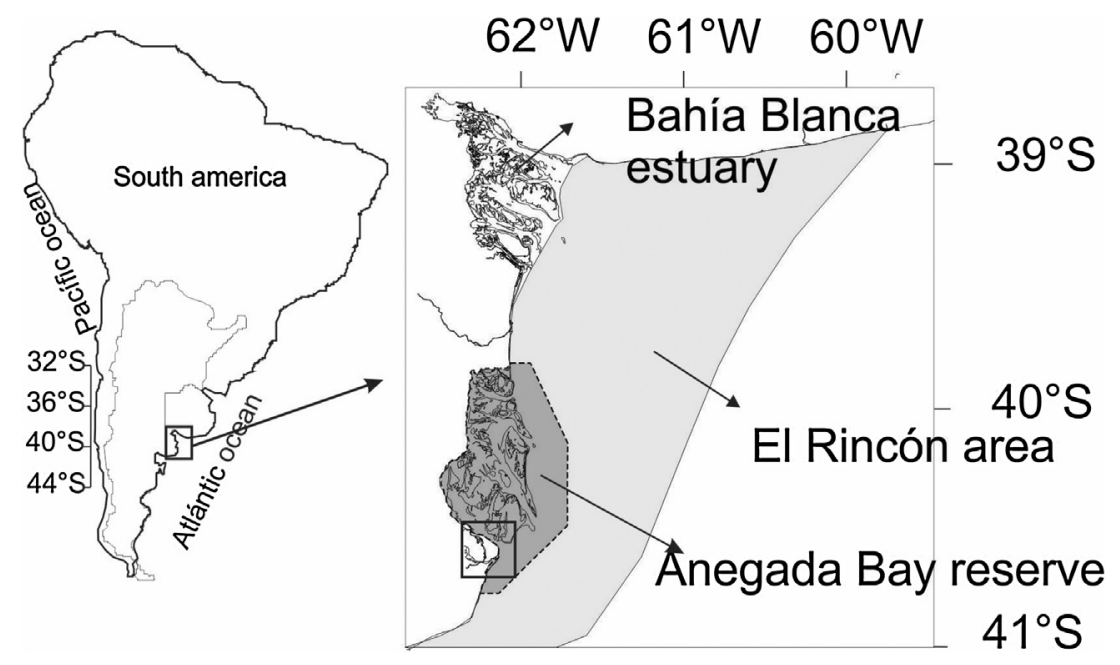

Fig. 1. Geographic location of study area. Dotted line showed the boundary of the Anegada Bay protected area.

monthly time to obtained the total catch along the year. These values were contrasted with the CPUE expressed by the fishing guides during interviews $(\mathrm{N}=28)$ and then expanded for the same total monthly fishing time. Since very similar values were obtained this result is not showed in this paper (but see Llompart, 2011).

For both types of recreational fisheries, catch data reflect the total once since locally catch and release of any species or size is negligible, except for mandatory release of large coastal sharks (Llompart, 2011). This fishery is an off-shore specialized recreational activity oriented to the exclusive catch of large size sharks (Carcarhinus brachyurus, Galeorhinus galeus, Notorynchus cepedianus and Carcharias taurus) that take place in the outer side of the bay (Lucifora, 2003). However, as such fishery does not present any interference and overlapping with the AF, SRF and BRF it is excluded from the present study.

\subsubsection{Artisanal fishery}

This traditional activity operated with small boats and within the first 3-5 nautical miles from the shoreline and took place between October 15 and December 15 of each year. This fishery had a daily pattern, setting the bottom gillnets in the afternoon and then picking them up the next morning. The fishing gear was regulated by the provincial authority which dictated that must be no more than seven bottom gillnets in each boat, with each one having a maximum length of $50 \mathrm{~m}$ and a minimum mesh size of $105 \mathrm{~mm}$ between the opposite knots.

The captures from the artisanal fishery were assessed for 2003-2007 period from the official landings records of the Ministerio de Asuntos Agrarios de la Provincia de Buenos Aires. The landings records included target and by-catch species in weight, but there were no data available about poaching or illegal catch. In addition, during 2007, three random fisherfolks were selected during four fishing trips and samples catches were analysed to obtain the fish-length-frequency distribution. Supplementary data to assess the AF activity, such as the composition of the catch species, the harvest, and the CPUE in $\mathrm{kg} \mathrm{h}^{-1}$, were re-analysed from Colautti et al. (2010). Finally, fishermen were interviewed $(N=11)$ to obtain a socio-economic perspective.

Based on data provided by fishers in the proposed management plan of San Blas Bay (Zalba et al., 2008) the distribution of AF and $\mathrm{RF}$ fishing areas was mapped and the potential spatial overlapping measured by mean of GIS software.

The intrinsic vulnerability index (Cheung et al., 2007) for landings of RF and AF was calculated from the intrinsic vulnerability index of the main target species available in FishBase (Froese and Pauly, 2016), and weighted by their annual catch.

\section{Results}

\subsection{Spatio-temporal distribution of fishing efforts and fisheries characterization}

The SRF was an annual activity employing 304,532 fishing hours per year. The SRF effort exhibited a considerable increase during spring and in the summer months (named the fishing season), especially during January (Fig. 2). Comparatively, the BRF fishing season started later in October and finished during the middle of April, involving approximately 45,000 fishing hours per fishing season. The boats available to rent were entirely built after the 2000 year and $80 \%$ were constructed by fiberglass ranging from 12 to $5.8 \mathrm{~m}$ in length (mean $7.3 \mathrm{~m} \pm 1.3 \mathrm{~m}$ ) with engines between $205 \pm 65$ horsepower and remodeled to provide comfort to anglers (poses-rods, seats, etc.). It had an average value of 45,000 dollars. It realised an average of 1.3 daily fishing trips and the transport capacity was between 19 and 7 anglers (mean $10.2 \pm 3.2$ ) who paid 30 dollars (in 2010) per fishing trip. BRF guides interviewed came from the Buenos Aires province (85\%) where they were employed in traditional areas and only a $10 \%$ was always linked to fishing.

In contrast with the RF, the AF season was shorter and was concentrated only in the two spring months, when $95 \%$ of the fishing effort was detected, and thus, showed a clear accomplishment of the norm (Fig. 2). According to the fishing license provided by Provincial Fisheries Division only 7 fishermen in 2003 and 14 for the rest of the study period possessed legal licenses to fishing in Anegada Bay. All of the fishermen interviewed were Argentinean resident with at least 25 years of local experience in artisanal fishing. Three of them had wooden boats of $11.65 \mathrm{~m} \pm 1.3 \mathrm{~m}$ in length with internal motors and a maximum load capacity between 200 and 300 boxes of fish (about 35 kilogrammes of fish in each one). The others had boats composed by fiberglass averaging $6.5 \mathrm{~m} \pm 0.7 \mathrm{~m}$ in length, driven by outboard motors of $40-70$ horsepower and have an average maximum load capacity of $40 \pm 10$ fish boxes. The catch was sold fresh or filleted locally in villages, closed towns or exported. Artisanal fishermen as well as fishing guides declared that fishing was the most relevant economic income for their livelihoods.

Spatial distribution of fishing activity strongly differed according to fisheries types. Whereas the SRF occupied only a small sector almost limited to San Blas village neighbors, the BRF extended on 


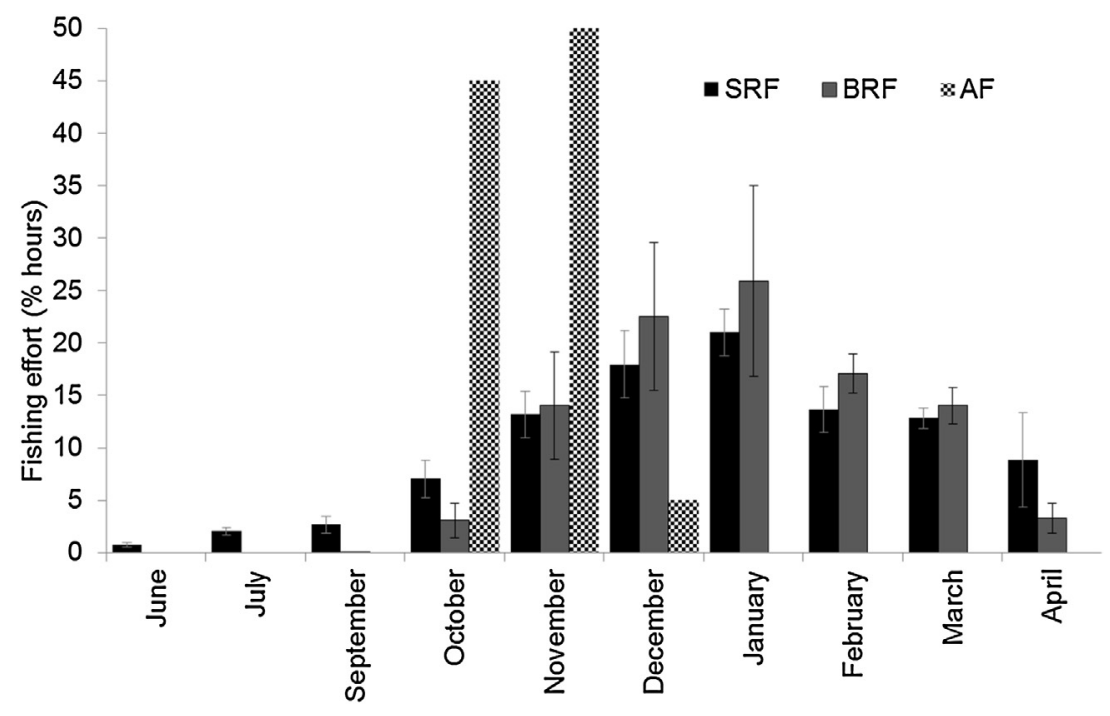

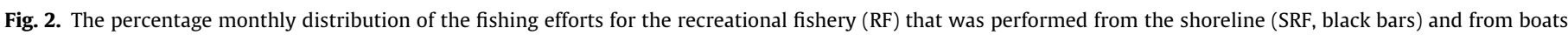
(BRF, grey bars), in comparison with the artisanal fishery (AF, dotted black and white).

Table 1

The catch per unit effort ( $\mathrm{Kg}$ fish $\mathrm{h}^{-1}$ ), the monthly catch (tonnes) discriminated by year and months, and the total yearly catch (in tonnes) by the artisanal fishery in Anegada Bay, according to the fishery log books. * During 2004 and after 2008, the artisanal fishery was banned due to conflicts.

\begin{tabular}{lllll}
\hline Year & Months & CPUE & Catch & Total \\
\hline 2003 & 10 & 17.9 & 49.4 & 108 \\
& 11 & 25.3 & 58.5 & \\
2005 & 10 & 12.6 & 56.3 & 254.3 \\
2006 & 11 & 14.1 & 198 & \\
& 10 & 18.1 & 107.6 & 169.6 \\
2007 & 11 & 8 & 59.7 & \\
& 12 & 2.9 & 2.29 & 146.7 \\
\hline
\end{tabular}

a larger area that include also outside reserve areas. In turn, the AF selected fishing ground patches located at the north part of the bay. The distribution of SRF and BRF did not show any spatial interaction but this was apparent between the AF and the BRF. In this case, the AF fishery shared almost $40 \%$ of its fishing areas whereas only $15 \%$ of the BRF was allocated in common area with the AF (Fig. 3).

\subsection{CPUE, monthly catches, vulnerability and the total harvest}

The CPUE values in the SRF increased during the spring months and reached a maximum during December, when the angler's catch rate was estimated as being 1.8 fish $^{-1}$ (Fig. 4). In turn, for the BRF, the mean seasonal CPUE values were estimated as being 6.8 fish $\mathrm{h}^{-1}$.

For the AF, the CPUE values varied among years but were similar on average in October $\left(18 \pm 4.4 \mathrm{~kg}\right.$ fish $\left.\mathrm{h}^{-1}\right)$ and November $\left(15.5 \pm 7.1 \mathrm{~kg}\right.$ fish $\mathrm{h}^{-1}$ ) (Table 1$)$.

Catch composition analysis showed that RF was based on few species. Indeed, the most prevalent species in the SRF were Cynoscion guatucupa (Cuvier, 1830), followed by Micropogonias furnieri (Desmarest, 1823), together accounting for $74 \%$ in weight of the total catch, whereas Mustelus schmitti (Springer, 1939) represented only $9.2 \%$ (Fig. 4). The monthly distribution of the SRF catch showed higher yields during December and with similar values during November and January.

The catch estimated for the BRF exhibited the same trend as did the SRF, where $89 \%$ of the total catch was accounted for by M. furnieri and C. guatucupa, followed by M. schmitti, which rep-

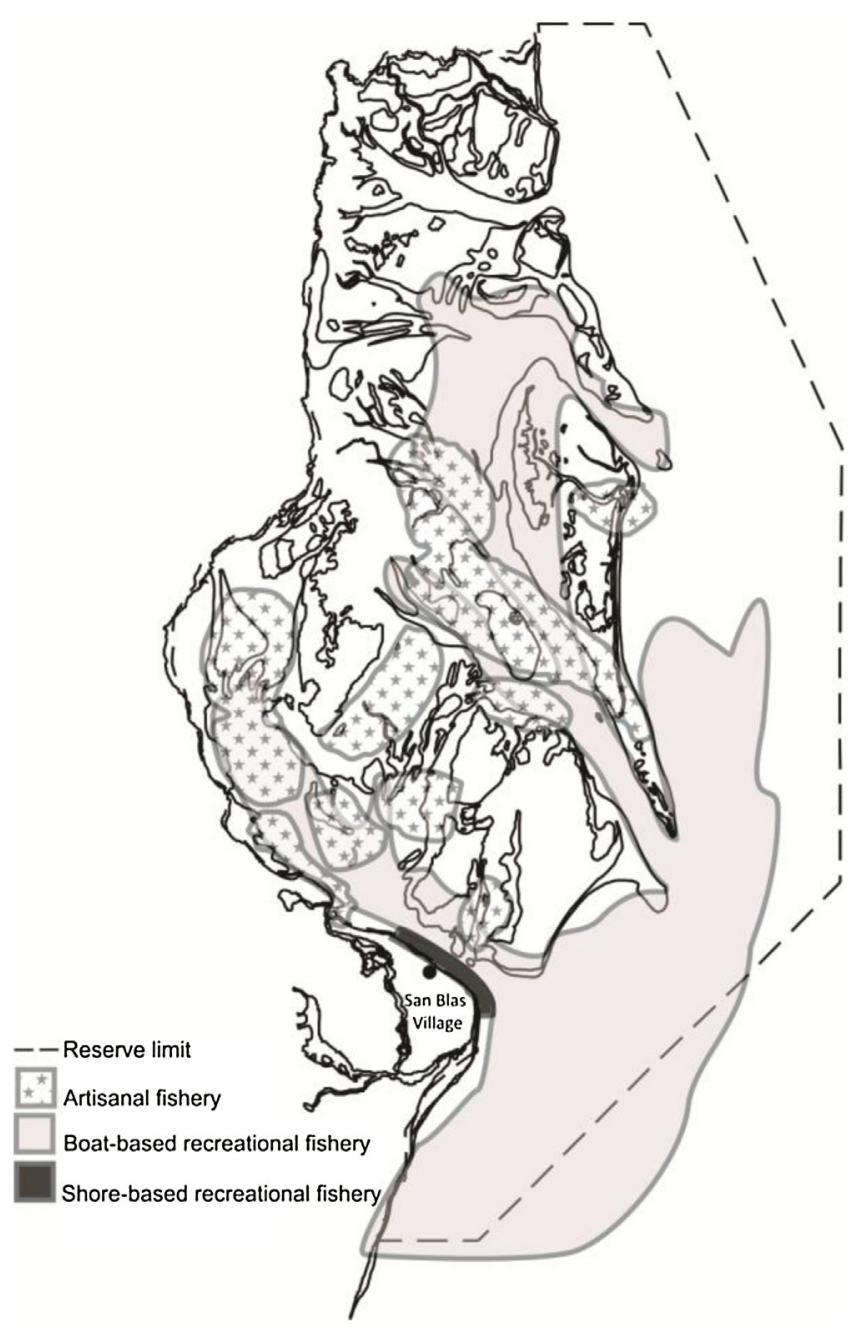

Fig. 3. Spatial distribution of recreational and artisanal fisheries in Anegada Bay.

resented only $7.9 \%$ of the total harvest in weight (Fig. 5). January was the month with the largest number of catches, followed by December and November. 


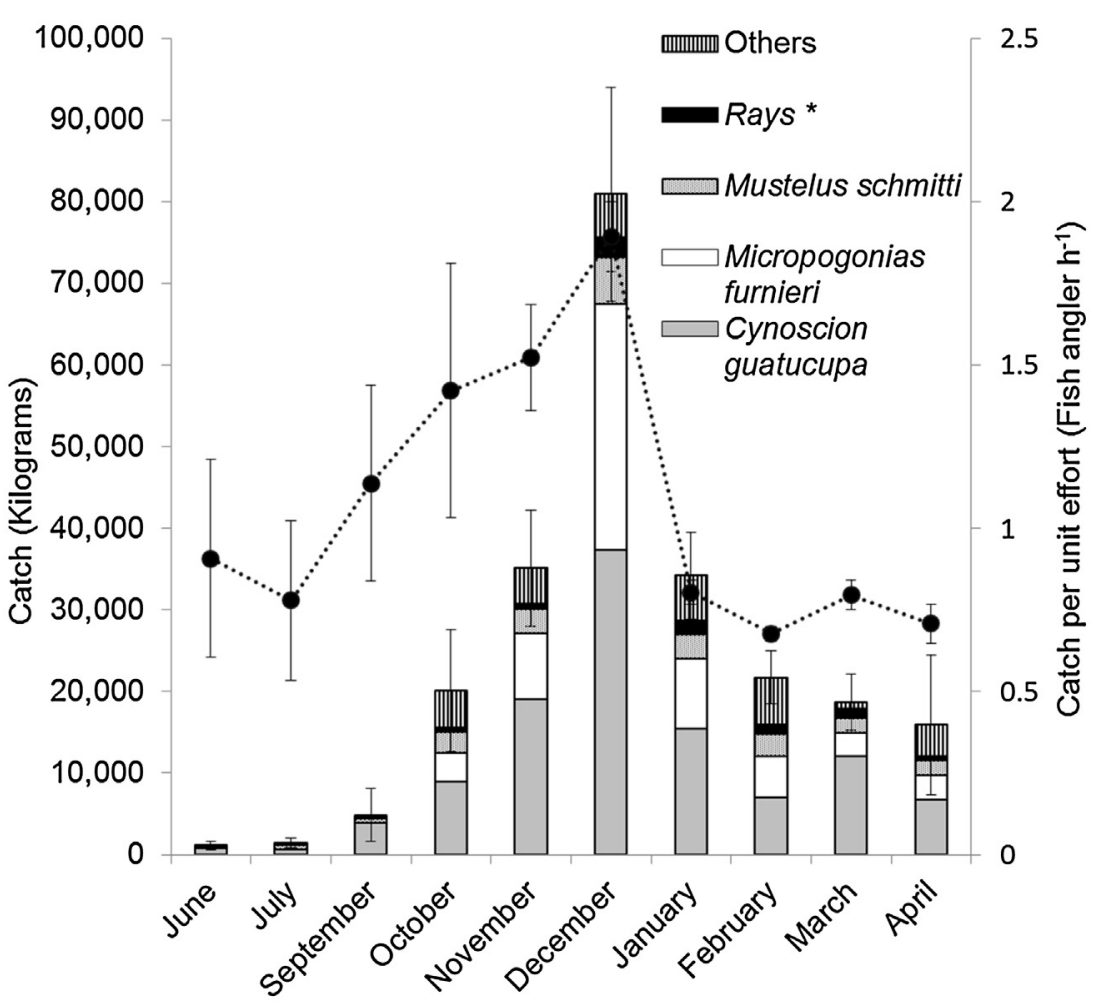

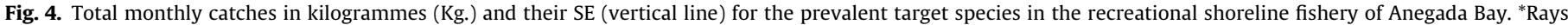
correspond to Sympterygia bonapartii + S. acuta species. The dotted line corresponds to the capture per unit effort (CPUE).

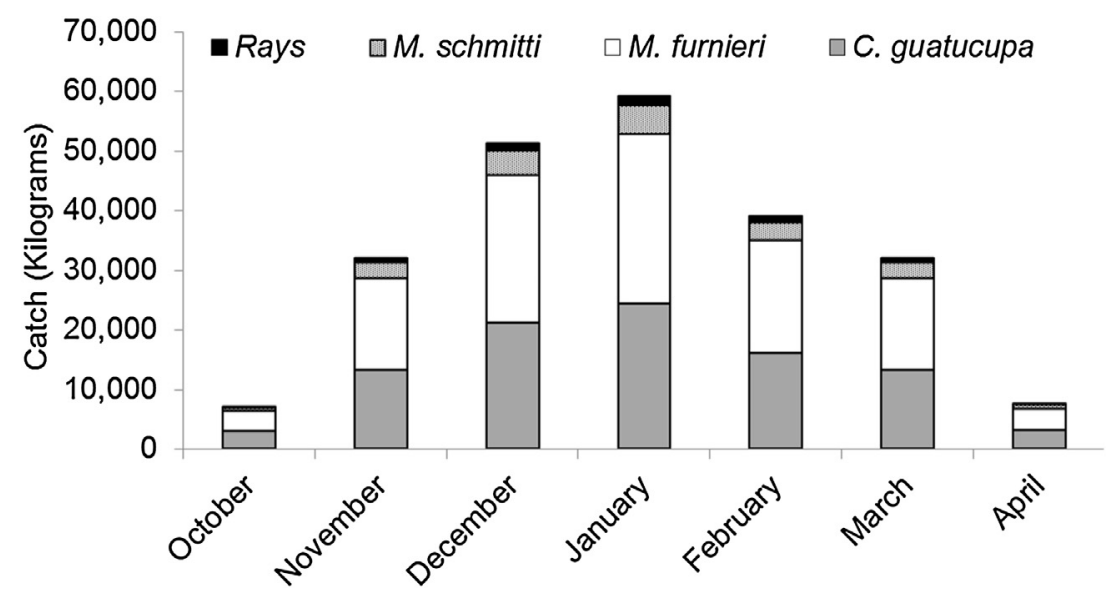

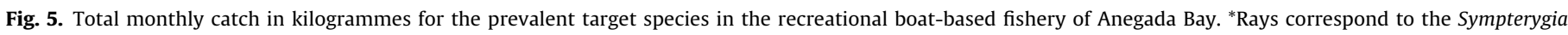
bonapartii + S. acuta species.

The two main target species of RF showed intrinsic vulnerability values of 40 for SRF and 32 for BRF (i.e. an average value between low to moderate vulnerability), but the rays extracted by the same fishery reached intrinsic vulnerability values above 70 (high to very high intrinsic vulnerability). The average intrinsic vulnerability for RF landings was 36.25 (out of 100), a level considered as moderate to high.

On the other hand, the AF captures were strongly dominated by M. schmitti (96\%), which indicates that this activity was almost mono-specific. A similar monthly yield trend was apparent in the AF among years where $42 \%$ of the total catch was recorded during October and $57.7 \%$ during November, while only $0.3 \%$ corresponded to December (Table 1). For M. schmitti an intrinsic vulnerability value of 58 (high vulnerability) was estimated. The AF intrinsic vulnerability of landings was 57.6 due to the almost monospecific extraction. The RF annual total harvest ( $\mathrm{SRF}+\mathrm{BRF}$ ) was estimated as being $462 \mathrm{t}$ whereas the AF annual harvest varied between $108 \mathrm{t}$ and $254.3 \mathrm{t}$ (Table 1 ). In any case, the AF mean across the years (169.7 \pm 61.8 tonnes) was a figure 2.7 times smaller respect to the total annual harvest of the RF.

\subsection{Fish lengths and anglers preferences}

The average total length (TL) recorded for the captures of $M$. schmitti in the RF $(53.8 \pm 7.1 \mathrm{~cm})$ was shorter than the minimum legal size ( $60 \mathrm{~cm}$, Provincial Fisheries Authority) and also for their length at first maturity estimated for this species in Anegada Bay [ $q=56.3 \mathrm{~cm}$, and $o^{x}=54.6 \mathrm{~cm}$, (Colautti et. al 2010) $]$. In contrast, the AF captures of $M$. schmitti had a size distribution that ranged from $44 \mathrm{~cm}$ to $87 \mathrm{~cm} \mathrm{TL}$, with a well-defined modal value at $64 \mathrm{~cm}$. 


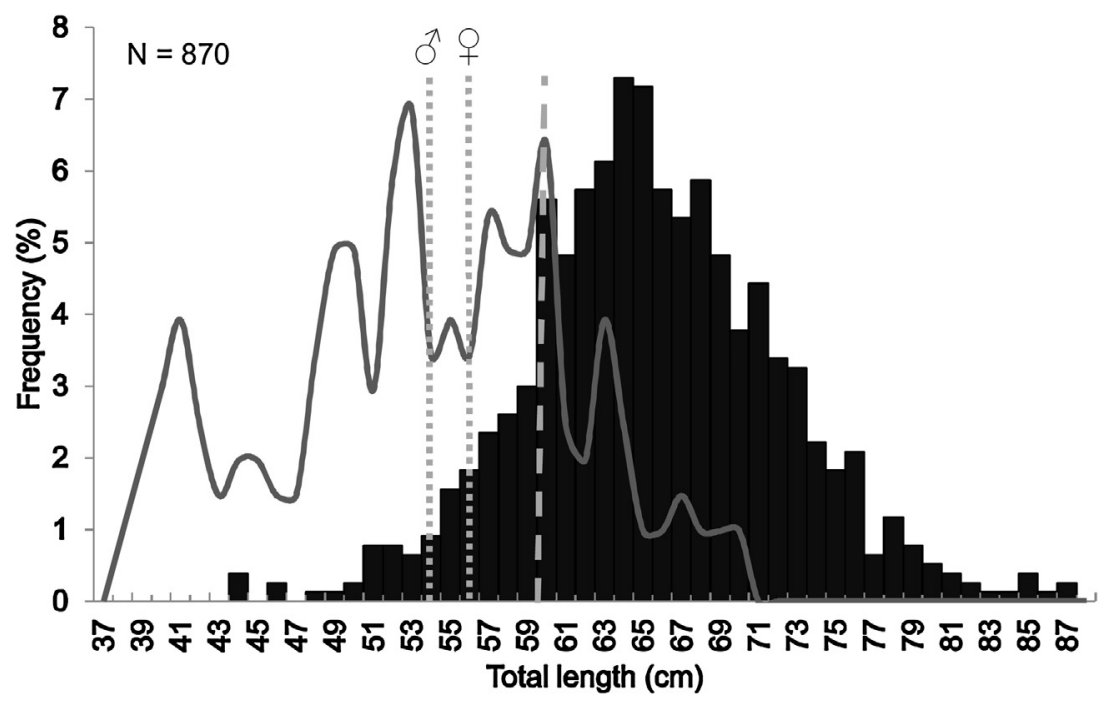

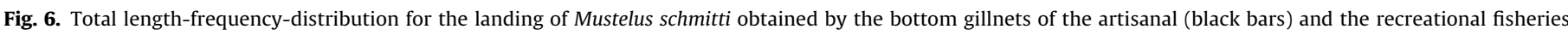

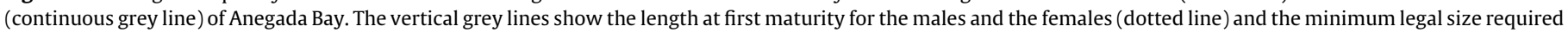
by the Provincial Fishery Authority (striped line).

Although this distribution included both sexes, it was noted that only $3.3 \%$ of the captured female were below the length at first maturity while this was $7.6 \%$ for males. Also, $15 \%$ of the captured AF fish corresponded to fish below the RF minimum legal size (Fig. 6).

In turn, the average $\mathrm{TL}$ of the RF catches for $M$. furnieri and C. guatucupa were $53.4 \mathrm{~cm}$ and $43.2 \mathrm{~cm}$, respectively, with both of these lengths being greater than the lengths at first maturity $\left(q=36 \mathrm{~cm}\right.$ and $o^{x}=34 \mathrm{~cm}, q=35 \mathrm{~cm}$ and $\sigma^{x}=30 \mathrm{~cm}$ ) and larger than the minimum legal size $(35 \mathrm{~cm}$ and $30 \mathrm{~cm}$ ), respectively (Cousseau and Perrotta, 2000; Provincial Fisheries Authority).

The interviewed anglers $(n=856)$ came from 12 different provinces of the country and half of them traveled more than 900 kilometers for fishing in Anegada Bay. Among them, 73\% believed that this bay was the best place for marine coastal fishing in Argentina. The monthly fishing quality, as reflected by the angler's opinions, was felt to be more positive during December, followed by November and October, in a descendent order. With respect to the targeted species, $M$. furnieri was selected by the anglers as their preferred fish (47\%) and C. guatucupa was the second-most preferred species (16\%) while any angler mentioned preference to catch M. schmitti.

\section{Discussion and conclusions}

This study represents a first attempt to examine the main management problems that have been identified in the most relevant marine recreational fisheries of North Patagonia, and thus, provides clues in order to understand the various conflicts and the governance limitations. Traditionally, main reasons for the conflicts in Anegada Bay have been related to the perception that the (ancient) AF can impact strongly on local fish assemblage and could also affect the RF quality. However, Brown (2016) recently demonstrated that the closure of net fisheries not produced an improvement of Queensland's recreational fisheries performance. Stakeholders have promoted the wrong idea when viewing artisanal fishing in the bay as a lucrative activity that uses fishing gear (nets) for the massive extraction of fish, with a high environmental cost, while recreational fishing has been conceived as a public and sporadic activity that is realised only for fun and being environmental friendly and without visible impact on fish resources (however, see Lewin et al., 2006). Even more, there is an increasing evidence showing that recreational fisheries could strongly affect threatened and overfished species and promoting biological changes on stocks similar to commercial fisheries (e.g. Schroeder and Love, 2002; Post et al., 2002; Coleman et al., 2004; Cook and Cowx, 2004).

\subsection{Disentangling temporal and spatial fishing patterns}

Fishing efforts and performances are strongly associated with the fish species dynamic, and thus, they represent key factors that are needed to understand the recreational and artisanal activities. Although the SRF is practised throughout the year, this fishery type along with BRF shows clear different peaks of fishing efforts during November to March as also is displayed by monthly catches and CPUE maximum values. This can be related to a seasonally increase in the abundance of their main target species according to the rise in sea water temperatures and due to their reproductive migration patterns (Llompart et al., 2010; Llompart, 2011; Llompart et al., 2013a). In contrast, the AF had a very limited fishing season of only two months per year, but with similar efforts and harvest rates during October and November (except when the AF operated only once in December 2006, solely catching $1.3 \%$ of the mean total harvest). This short fishing season obeyed not only to the temporal regulatory constraints made by the fishery authority, but also because it is during these months when the adult population fraction of the target species inhabits the coastal areas of the bay (Colautti et al., 2010). According to these fishing patterns, only a partial level of temporal overlapping between both fisheries sectors existed during November. Indeed, October appears to be important for the AF, but much less relevant for the SRF and the BRF, since only $7 \%$ and $3 \%$ for the total efforts and $8 \%$ and $3 \%$ for the total catch, respectively took place during this month. However, during November, the AF obtained nearly half of the total catch, coinciding when the SRF and the BRF had already increased their activities (13\% and 15\% for the total effort and $15 \%$ and $14 \%$ for the total catch, respectively). During December, the AF mostly did not operate, while such a month was better for the SRF in terms of the CPUE, the catch, and the angler's preferences. The higher fishing efforts for the SRF and the maximum monthly catch for the BRF were registered during January, when the AF had ended the fishing season.

Artisanal and recreational fisheries exhibited different spatial distribution patterns. Whereas the SRF did not overlapped with the $\mathrm{AF}$, the BRF occupied by far the most extensive area which included at least $40 \%$ of AF fishing grounds. Such overlapping could be rele- 
vant and promote conflicts especially during November, even when both fisheries almost not shared the main target species. Nonetheless, conflicts regarding the competition for the space can take place as was found in others fisheries (Pawson et al., 2008; Lloret et al., 2008). Field experiences indicated that anglers have not good predisposition to observe fishing nets in "their" fishing areas due to a potential decline in the recreational fishing quality. Prioritizing agreed fishing areas between resource users along with independent and distant ports of landings could decrease the visual contact between fisheries sectors and thus reduce the spatial conflict. In addition, as was successfully implemented in many coastal areas around the world, diversification from traditional fishing into others activities such as ecotourism within the marine protected area could represent a sustainable and alternative way to acquire economic benefit.

In San Blas intrasectoral conflicts are alleviated due to difference in the target species. The SRF and the BRF greatly focused their catches on C. guatucupa and M. furnieri, which together accounted for three quarters of their total harvest in weight. For the AF, $M$. schmitti was nearly the single species captured, with negligible captures of C. guatucupa and M. furnieri as by-catch. Moreover, $M$. schmitti was not even mentioned as being preferable for the recreational anglers, and therefore, their captures were produced involuntarily.

The average intrinsic vulnerability for by the RF fish catches reached a value lower than the average vulnerability of all worldwide exploited coastal fish species (48 out of 100) (Cheung et al., 2007). On the other hand, the average intrinsic vulnerability of AF catch was higher than the previous reference value. These results are consequence of the biological characteristic for the main target species (M. schmitti). In this sense, AF clearly exerted its fishing pressure on a more vulnerable species, particularly when the adult population fraction enter into the bay for birth and mating purposes. The extraction of large individuals by AF could adversely affect the reproductive potential of $M$. schmitti populations, particularly if it is considered that larger females are proportionally more fecund (Oddone et al., 2007). Despite the RF had an intrinsic vulnerability lower than AF its catch not only included M. schmitti but also two rays species (Sympterigia bonapartii and S. acuta) that showed high intrinsic vulnerability status (Cheung et al., 2007). This situation demands the urgent implementation of conservation policies for $\mathrm{AF}$ and $\mathrm{RF}$ in order to protect the most vulnerable target species.

\subsection{Comparison of catch lengths and the total harvest between the fisheries}

The target species captured by the RF (M. furnieri and C. guatucupa) were above the minimum legal size and their length at first maturity. However, the capturing of $M$. schmitti, although represent a lower percentage of the total catch, was below the minimum legal size for the species. Such features can be related to the presence of juveniles during the autumn and winter months in the area, when they are caught by unselective baited-hooks and rigs. In contrast, since the AF operated only with selective bottom gillnets, and only when the adult population fraction migrated into the bay, a small percentage of the sharks captured were above the legal size. Moreover, the AF captures were identified as being comprised of $1 \%$ juveniles (less than $50 \mathrm{~cm} \mathrm{TL}$ ) and $27.7 \%$ of young adults (less than $62.5 \mathrm{~cm} \mathrm{TL}$ ), according to the categories suggested by Colautti et al. (2010).

A main characteristic of both fisheries is that they can be considered selective due to they are concentrated on only few species. These issues preclude applying a more balanced fishing approach that distributes the effort among different species. Selective fishing can results in target and non-target species being killed disproportionately to their abundances, modifying their roles in natural assemblages, and intrinsic capacities to sustain impacts (Zhou et al., 2010). However, the dominant species of the Anegada Bay fish assemblage are $C$. guatucupa, $M$. furnieri and $M$. schmitti (Llompart et al., 2013a) which were also identified as the most typical ones for the inner coastal assemblage of Argentina (Jaureguizar et al., 2006). Therefore, both fisheries are based on the most abundant species in the bay. The diversification of AF catches could be also possible towards Odontesthes argentinesis (see Llompart et al., 2013b).

In addition, new regulations especially for vulnerable species in Anegada Bay need to focus on catch lengths more than in total harvest. In this sense, size selection of $M$. schmitti population appears to be happened in Anegada Bay. The RF affects the juvenile and young-adult population fraction while AF extracted the larger size individuals. Oddone et al. (2007) found that the litter size of $M$. schmitti appears to be linearly related to the pregnant female's length. This is why selective catching large size favours genotypes with slower growth producing evolutionary changes with time. Meanwhile, target size below the first length at maturity has impacts on the reproductive potential of the stock (Lloret et al., 2012). To acquire sustainability, a mandatory catch and release fishing for RF was proposed for juveniles of $M$. schmitii that not have sport nor monetary value (Llompart et al., 2012). The same regulation should be implemented on other target and non-target species with high vulnerability indices such as chondricthyans. For example, RF catches are directed to other vulnerable species such as Myliobatis spp. and Atlantoraja castelnaui but only during tournaments by weight (Llompart, 2011) while rays are frequent SRF and BRF by-catch species. Since fish mortality rates after release depend strongly on the fishing tackle used and angler behaviour (see the Special Issue: The Science and Practice of Catch-and-Release Angling, published in Fisheries Research, volume 186, 2017) educating anglers in science-based best angling practices is relevant to minimize negative impacts. Finally, to decrease the proportion of large size M. schmitti in the AF catch, a length frequency distribution analysis but using experimental gill nets containing smaller mesh size between opposite notes $(100 \mathrm{~mm})$ could be useful to be tested and implemented. Also, a continuous monitoring program to acquire fishery-independent information to evaluate catch lengths, by-catch levels and fishing effort should be performed.

The results from the total harvest of the RF sector proved to be almost three times that of the AF, being the SRF largely more important than the BRF in terms of anglers involved and fishing effort. This is in agreement with different studies that have reported higher catches by the recreational fisheries when compared to the commercial harvest (Schroeder and Love, 2002; Pawson et al., 2008) and this highlights the potential impacts of this activity. However, both coastal fisheries in Anegada Bay appear to be having a low impact at a regional scale. When the species are considered at a broader geographical area it is important to note that outside of the marine reserve area (in the el Rincón area), a multi-specific commercial bottom trawling fishery industry (practised mostly by vessels between $18 \mathrm{~m}$ and $39 \mathrm{~m}$ in length), capture about 20,000 t of fish per year (Aráoz and Carozza, 2014), of which 3000 t correspond to M. schmitti (total of $8500 \pm 2267$ tonnes at national level between the 1990-2015 period). This has reduced their biomass by $50 \%$ between 1994 and 2003 (Massa and Hozbor, 2003; Massa et al., 2004) and currently M. schmitti is categorized as endangered species by UICN (Massa et al., 2006). Species with high intrinsic vulnerability to exploitation and intensively fished are more prone to have high risk of population depletion and extinction (Cheung et al., 2005). Conversely, in Anegada Bay a total harvest of nearly $631 \mathrm{t}$ annually ( $\mathrm{RF}+\mathrm{AF})$ of which $208 \mathrm{t}$ correspond to $M$. schmitti is sufficient to support the local population of nearly 800 residents and thousands of tourists per year. Such numbers highlight that a well administered small scale fishery, particularly in developing countries, could represent the best option for the sustainable utilisation 
of coastal resources, especially if they meet most of the criteria that are required for an enlightened fisheries policy, in terms of supporting employment, livelihood, and food security (Pauly, 2006).

\subsection{Fishery management directions}

Conflicts between artisanal and recreational fisheries have been addressed for different marine fisheries elsewhere (e.g. Kearney, 2002; Morales-Nin et al., 2005; Lloret et al., 2008; Veiga et al., 2010; Brown, 2016). Most of such examples corresponded to fisheries managed under command-control and centralized approaches that do not emphasize the need to find win-win solutions for both sectors. While fisheries management objective need to be shifted toward preserving the integrity of the ecosystems and biological diversities as well as assuring social sustainability, it is critical to move from such conventional approaches that fail to ensure equity benefits and solve multi-stakeholder conflicts.

Problems and management constraints in Anegada Bay align also with common limitations observed in different Latin American fisheries where poor institutional structures, ineffective control of fishing efforts, poor enforcement of their policies and weak frameworks to integrate social, bio-ecological, and economic aspects promote recurrent conflicts (Salas et al., 2007; Arlinghaus, 2008). For example, although the management plans for the multiple-use of the natural reserves in the San Blas Bay promoted the development of artisanal fisheries in a sustainable way, considering their historical and cultural value (Zalba et al., 2008), anyway it was banned. The absence of consistency in management propositions reduces the mutual credibility for future cooperative actions. Appropriate incentives that are offered by the management system, primarily to the fishermen (but also to managers, scientists, and other stakeholders), may be the only alternative to achieve compliance (Orensanz et al., 2005).

To resolve intra-sectoral conflicts in the long term, an efficient communication process between the fishery sectors is requested (Newton and Ellio, 2016). The actual barriers that impair a good communication between the sectors, such as a lack of rigorous scientific information, need to be overcome and transferred from the researchers to the fishers and the managers by promoting better mechanisms and collective efforts to focus on effective participatory management and conservation guidelines. A fear from the fishermen of management actions, which could limit their fishing opportunities, together with the fisher's suspicions of science, still represent a barrier to improve the collaboration and to find robust management actions, for the equitable and the optimal use of common-pool resources by coastal fisheries (Dedual et al., 2013).

Moreover, since the migratory behaviour of the main target species for AF and RF fisheries in Anegada Bay (Llompart et al., 2013a,b) belong to the same stock exploited by the industrial trawl fisheries that operate in El Rincón area (Jaureguizar et al., 2006), a more comprehensive management plan must be implemented at a regional scale (Colautti et al., 2010). Only from this integrative perspective it is possible to achieve a better comprehensive picture of the current status of the stocks health, their potential change for recovery and to find a balance between risks and opportunities offered by each fishery.

However, fishery sustainability is dependent not only from a fishing perspective but should also encompass other equally important dimensions (Charles, 2001). Inter-sectoral conflicts with no-fishing stakeholders, conservationist demands, and wildlife watchers should be considered as well. The nature of the multiple uses of common pool resources in Anegada Bay by local residents, fishers, and tourists in general, dictate that these activities can no longer be treated in isolation and requires more comprehensive governance guidelines. Recovering of artisanal fishery activity could be difficult without changing management paradigms. An adaptive co-management approach for small scale fisheries is emerging in Latin America as a potential solution to enhance the capability of the governing system (Castrejón and Defeo, 2015; Trimble and Berkes, 2015). In this context, the promotion of recreational fisheries at the expense of, or in conjunction with the artisanal fisheries, together with a transformation of the conflictive relationships, to one of collaboration, constitutes a governability challenge that is ultimately reliant on self-regulated systems, with only a slight intervention by the public hand (Berkes, 2003).

The fact that the recreational and artisanal fisheries exhibit a weak temporal overlapping and because anglers prefer $M$. furnieri and C. guatucupa as target species while AF is directed to M. schmiiti, represents an advantage to reduce the conflicts of a common use of coastal resources in Anegada Bay. Moreover, during November when both sectors share a proportion of common fishing grounds areas, a situation-specific Territorial Use Right in Fisheries strategy could be appropriate to ameliorate potential conflicts as was implemented in other Latin American small-scale fisheries (Defeo et al., 2016). In Anegada Bay, such strategy implies allocating exclusive rights for artisanal fishers in certain areas especially during November. As RF occupies larger extensions, but main activity take place during summer months, such a measure would not impact on their performance nor reduce angler expectative and satisfaction.

Future directions also should be complemented with regular and improved monitoring of both fisheries addressing the potential for catches underreports, miss reported landings and illegal catch selling and poaching. Further, in this study, fisheries data from BRF lacked of enough technical details as was for the SRF, thus requiring some caution with data comparison and interpretation.

There is an urgent need to evaluate not only the potential impact that the different types of fishing activities and their effects on the sustainability of coastal resources and on the general functioning of coastal ecosystems, but also on supporting livelihoods for local people. Close a net fishery is only likely to increase recreational harvest if net harvest is larger relative to recreational harvest (Brown, 2016), however this was not the case in Anegada Bay. Indeed, this study provided strong evidences that limited total harvest of both fisheries, their slight overlap in temporal and spatial scales, along with different targeted species due the selectivity of the gear uses and the angler's preferences provide favourable conditions for reconciliation. Instead of considering as direct "competitors" AF and RF should allow for a sustainable co-existence in the bay, without compromising the conservational goals pursued by the natural protected area.

\section{Acknowledgments}

Financial support from the PAE No. 22666/04-ANPCyT is gratefully acknowledged. We thank local fishermen and stakeholders for providing valuable support for data collection and field operations. The authors are also thankful to two anonymous reviewers that contributed with their corrections and suggestions to improve the manuscript.

\section{References}

Allison, E.A., Ellis, F., 2001. The livelihoods approach and management of small-scale fisheries. Mar. Policy 25, 377-388.

Andrew, N.L., Béne, C., Hall, S.J., Allison, E.H., Heck, S., Ratner, B.D., 2007. Diagnosis and management of small-scale fisheries in developing countries. Fish Fish. 8, $227-240$.

Aráoz, F.N., Carozza, C., 2014. Asociación Íctica costera bonaerense variado costero Capturas declaradas por la flota comercial Argentina durante el año 2014. INIDEP No. 20, 18pp.

Arlinghaus, R., 2005. A conceptual framework to identify and understand conflicts in recreational fisheries systems with implications for sustainable management. Aq. Res. Cult. Dev. 1, 145-174. 
Arlinghaus, R., 2008. Social barriers to sustainable recreational fisheries management under quasi common property fishing rights regime. Am. Fish. Soc. Symp. 49, 105-122.

Béné, C., 2006. Small-scale fisheries: assessing their contribution to rural livelihoods in developing countries. Rome: FAO Fisheries Circular No. 1008.

Berkes, F., Mahon, R., McConney, P., Pollnac, R.C., Pomeroy, R.S., 2001. Managing small-scale fisheries: alternative directions and methods. International Development Research Centre, Ottawa.

Berkes, F., 2003. Alternatives to conventional management: lessons from small-scale fisheries. Environment 31,1-14.

Borges, M.E., 1997. Conservación de la Bahía Anegada. Ministerio de Asuntos Agrarios. Dirección Provincial de Pesca. La Plata. Reporte Técnico No. 17/97, $15 \mathrm{pp}$

Borges, M.E., 2006. Ecología de las ostras en ambientes del sur bonaerense: Cultivo y manejo de sus poblaciones. Tesis Doctoral. Universidad Nacional del Sur, pp. 265pp

Brown, C.J., 2016. Social: economic and environmental effects of closing comercial fisheries to enhance recreational fishing. Mar. Policy 73, 204-209.

Castrejón, M., Defeo, O., 2015. Co-governance of small-scale shellfisheries in Latin America: institutional adaptability to external drivers of changes. In: Interactive Governance for Small-scale Fisheries. MARE Publication Series.

Charles, A.T., 2001. Sustainable fishery systems. Blackwell Science Ltd, London, 370 pp.

Cheung, W.W.L., Pitcher, T.J., Pauly, D., 2005. A fuzzy logic expert system to estimate intrinsic extinction vulnerabilities of marine fishes to fishing. Biol. Conserv. 124, 97-111

Cheung, W.W.L., Watson, R., Morato Pitcher, T.J., Pauly, D., 2007. Intrinsic vulnerability in the global fish catch. Mar. Ecol. Prog. Ser. 333, 1-12.

Chuenpagdee, R., Liguori, L., Palomares, M.L.D., Pauly, D., 2006. Bottom-up, global estimates of small-scale marine fisheries catches. Fish. Cent. Res. Rep. 14 (8), 110pp

Chuenpagdee, R., 2011. Too big to ignore. Global network for the future of small scale fisheries. In: Chuenpagdee, R. (Ed.), World Small Scale Fisheries: Contemporary Visions. Eburon Delft.

Colautti, D., Baigún, C., López, C.A., Llompart, F., Molina, J.M., Suquele, P., Calvo, S. 2010. Population biology and fishery characteristics of Smoothhound Mustelus schmitti in Anegada Bay, Argentina. Fish. Res. 106, 351-357.

Coleman, F.C., Figueira, W.F., Ueland, J.S., Crowder, L.B., 2004. The impact of United States recreational fisheries on marine fish populations. Science 305, 1958-1960.

Cooke, S.J., Cowx, I.G., 2004. The role of recreational fishing in global fisheries. Bioscience 54, 857-859.

Cooke, S.J., Cowx, I.G., 2006. Contrasting recreational and commercial fishing: searching for common issues to promote unified conservation of fisheries resources and aquatic environments. Biol. Conserv. 128, 93-108.

Cousseau, M.B., Perrotta, R.G., 2000. Peces marinos de Argentina. Biología, distribución, pesca. Mar del Plata-Argentina. INIDEP, 167p.

Dedual, M., Sague Pla, O., Arlinghaus, R., Clarke, A., Ferter, K., Geertz-Hansen, P., 2013. Communication between scientists recreational fishers, fishery managers and recreational fishers: lessons learned from a comparative analysis of international case studies. Fish. Manage. Ecol. 20, 234-246.

Defeo, M., Castrejón, M., Pérez-Castañeda, R.P., Castilla, J.C., Gutiérrez, N.L., Essington, T.E., Folke, C., 2016. Co-management in Latin American small-scale shellfisheries: assessment from long-term case studies. Fish Fish. 17, 176-192.

Defeo, O., 2014. Enfoque ecosistémico pesquero: Conceptos fundamentales y su aplicación en Uruguay. Final Report, Project CP/URU/030/GFF Piloting of an Ecosystem-based Approach to Living Aquatic Resources Management. DINARA, Uruguay (p. 99).

Elías, I., Carozza, C., Di Giácomo, E., Isla, M., Orensanz (Lobo), J.M., Parma A.M., Pereiro, R.C. Perier, M.R., Perrotta, R.G., Ré, M.E. and Ruarte, C., 2011. Coastal fisheries of Argentina. In: Coastal fisheries of Latin America and the Caribbean (Salas, S., Chuenpadgdee, R., Charles, A., and Seijo, J.C. eds.). FAO Fisheries and Aquaculture Technical Paper. No. 544. Rome, FAO. 430p.

FAO, 2012a. Recreational fisheries. FAO Technical Guidelines for Responsible Fisheries. No. 13. FAO, Rome, pp. 2012, 176 pp.

FAO, 2012b. Voluntary guidelines of the responsible governance of tenure of land fisheries and forests in the context of national security. FAO, Rome, 40pp.

Froese, R., Pauly, D. (Eds.), 2016. World Wide Web electronic publication, www. fishbase.org version (06/2016).

Jaureguizar, A.J., Menni, R., Lasta, C., Guerrero, R., 2006. Fish assemblages of the northern Argentine coastal system: spatial patterns and their temporal variations. Fish. Oceanogr. 15, 326-344.

Jentoft, S., Chuenpagdee, R., 2009. Fisheries and coastal governance as a wicked problem. Mar. Policy 33 (4), 553-560.

Jentoft, S., 2000. The community: a missing link of fisheries management. Mar. Policy 24, 53-60.

Kearney, R.E., 2002. Co-management: the resolution of conflict between commercial and recreational fishers in Victoria, Australia. Ocean Coast. Manage. 45, 201-214.

Lasta, A.C., Ruarte, C.O., Carozza, C.R., 2001. Flota costera Argentina: antecedentes y situación actual. El mar argentino y sus recursos pesqueros 3, 89-106.

Lewin, W.C., Arlinghaus, R., Mehner, T., 2006. Documented and potential biological impacts of recreational angling: insights for conservation and management. Rev. Fish. Sci. 14, 305-367.
Llompart, F.M., Molina, J.M., Cazorla, A.L., Baigún, C.R., Colautti, D.C., 2010. Fish fauna from anegada bay protected area Buenos Aires province, Argentina. CheckList 127, 579-582.

Llompart, F.M., Colautti, D.C., Baigún, C.R.M., 2012. Assessment of a major shore-based marine recreational fishery in the Southwest Atlantic, Argentina. N. Z. J. Mar. Freshw. Res. 46, 57-70.

Llompart, F.M., Colautti, D.C., Cruz-Jiménez, A.M., Baigun, C.M., 2013a. Seasonal pattern of the coastal fish assemblage in Anegada Bay, Argentina. J. Mar. Biol. Assoc. U. K. 93 (8), 2273-2285.

Llompart, F.M., Colautti, D.C., Maiztegui, T., Cruz-Jiménez, A.M., Baigun, C.R.M., 2013b. Biological traits and growth patterns of pejerrey Odontesthes argentinensis. J. Fish Biol. 82, 458-474.

Llompart, F.M., 2011. La ictiofauna de Bahía San Blas (Provincia de Buenos Aires) y su relación con la dinámica de las pesquerías deportiva y artesanal. PhD thesis. Universidad Nacional de La Plata, Argentina.

Lloret, J., Zaragoza, N., Caballero, D., Font, T., Casadevall, M., Riera, V., 2008. Spearfishing pressure on fish communities in rocky coastal habitats in a Mediterranean marine protected area. Fish. Res. 94, 84-91.

Lloret, J., Muñoz, M., Casadevall, M., 2012. Threats posed by artisanal fisheries to the reproduction of coastal fish species in a Mediterranean marine protected area. Estuar. Coast. Mar. Sci. 113, 133-140.

Lucifora, L.O., 2003. Ecología y Conservación de los grandes tiburones costeros de Bahía Anegada. Provincia de Buenos Aires. Argentina. Tesis Doctoral. Universidad Nacional de Mar del Plata, 410p.

Malvestuto, S.P., Knight, S.S., 1991. Evaluation of components of variance for a stratified two-stage roving creel survey design with implications for sample size allocation. In: Guthrie, D., Hoenig, J.M., Holliday, M., Jones, C.M., Mills, M.J. Moberly, S.A., Pollock, K.H., Talhelm, D.R. (Eds.), Creel and Angler Surveys in Fisheries Management. American Fisheries Society, Bethesda, Maryland, pp. $108-115$.

Massa, A.M., Hozbor, N.M., 2003. Peces cartilaginosos de la plataforma Argentina: explotación, situación y necesidades para un manejo pesquero adecuado. Frente Marítimo 19, 199-206.

Massa, A.M., Lasta, C., Carozza, C., 2004. Estado actual y explotación del gatuzo (Mustelus schmitti). In: Sanchez, R., Veis, S. (Eds.), El Mar Argentino y sus recursos pesqueros Tomo 4. Biología y evaluación del estado de explotación. Pub. Esp. INIDEP, pp. 67-83.

Massa, A., Hozbor, N., Chiaramonte, G.E., Balestra, A.D., Vooren, C.M., 2006. Mustelus schmitti. The IUCN Red List of threatened species 2006: e.T60203A12318268., pp. 2006, http://dx.doi.org/10.2305/IUCN.UK RLTS.T60203A12318268.en. Downloaded on 08 September 2016.

Morales-Nin, B., Moranta, J., García, C., Tugores, M.P., Maria Grau, A., Riera, F. Cerda, M., 2005. The recreational fishery of Majorca Island (western Mediterranean): some implications for coastal resource management. ICES J. Mar. Sci. 62, 727-739.

Newton, A., Ellio, t.M., 2016. A typology of stakeholders and guidelines for engagement in transdisciplinary, participatory processes. Front. Mar. Sci., http://dx.doi.org/10.3389/fmars.2016.00230.

Oddone, M.C., Paesch, L., Norbis, W., Velasco, G., 2007. Population structure, distribution and abundance patterns of the Patagonian smoothhound Mustelus schmitti Springer, 1939 (Chondrichthyes, Elasmobranchii, Triakidae) in the Rio de la Plata and inner continental shelf, SW Atlantic ocean (34(30-39(30s). Braz. J. Oceanogr. 55, 17.

Orensanz, J.M., Parma, A.M., Jerez, G., Barahona, N., Montecinos, M., Elías, I., 2005. What are the key elements for the sustainability of 'S-fisheries'? Insights from South America. Bull. Mar. Sci. 30, 527-556.

Pauly, D., 2006. Major trends in small-scale marine fisheries, with emphasis on developing countries, and some implications for the social sciences. Mar. Stud. 4 (2), 7-22.

Pawson, M.G., Glenn, H., Padda, G., 2008. The definition of marine recreational fishing in Europe. Mar. Policy 32, 339-350.

Penchaszadeh, P.E., Borges, M.E., Damboronea, C., Darrigan, G., Obernat, S., Pastorino, G., Schwindt, E., and Spivak, E. 2003. Especies animales bentónicas introducidas, actual o potencialmente invasoras en el sistema del Río de la Plata y la región costera oceánica aledaña del Uruguay y de la Argentina. En Protección ambiental del Río de la Plata y su frente marítimo: prevención y control de la contaminación y restauración de hábitats. Proyecto PNUD/GEF RLA/99g 31. 357p.

Pitcher, T.J., Hollingworth, C.E., 2002. Recreational fisheries: ecological, economic and social evaluation. Fish and Aquatic Resources Series No 8. Blackwell Science, Oxford, UK, 288pp.

Pollock, K.H., Jones, C., Brown, T., 1994. Angler survey methods and their application in fisheries management. American Fisheries Society Special Publication No. 25, 371pp.

Post, J.R., Sullivan, M., Cox, S., Lester, N.P., Walters, C.J., Parkinson, E.A., Paul, A.J., Jackson, L., Shuter, B.J., 2002. Canada recreational fishery: the invisible collapse? Fisheries 27, 6-617.

Renae, C., 2006. The effectiveness of recreational only fishing areas in North Queensland estuaries for reducing conflict and improving recreational catches. PhD Thesis. James Cook University.

Robson, D.S., 1991. The roving creel survey. In: Gutrie, D., Hoenig, J.M., Holliday, M. Jones, C.M., Mills, M., Moberley, S., Pollock, K., Talheim, D. (Eds.), Creel and Angler Surveys in Fisheries Management, vol. 12. American Fisheries Society Symposium, pp. 19-24.

SHN, 2009. Servicio de Hidrografía Naval 2009, Available at: htttp://www.hidro gov.ar/oceanografia (Accessed 20 October 2009). 
Salas, S., Chuenpagdee, R., Seijo, J.C., Charles, A., 2007. Challenges in the assessment and management of small scale fisheries in Latin America and the Caribbean. Fish. Res. 87, 5-16.

Schroeder, D.M., Love, M.S., 2002. Recreational fishing and marine fish populations in California. California Cooperative Oceanic Fish. Invest. Rep. 43, 182-190.

Sudman, S., Bradburn, N.M., 1982. Asking questions: a practical guide to questionnaire construction. Jossey-Bass, Washinton D.C, 416pp.

Sullivan, P.J., Breidt, F.J., Ditton, R.B., Knuth, A.B., Leaman, B.M., O’Connell, M.V., Parsons, G.R., Pollock, K.H., Stephen, J.S., Stokes, S.L., 2006. Review of recreational fisheries survey methods. The National Academies Press, Washington D.C, 203pp.

Teh, L.C.L., Sumaila, U.R., 2013. Contribution of marine fisheries to worldwide employment. Fish Fish. 14, 77-88.

Trimble, M., Berkes, F., 2015. Towards adaptive co-management of small-scale fisheries in Uruguay and Brazil: lessons from using Ostrom's design principles. Mar. Stud. 14, 14.
Veiga, P., Ribeiro, J., Goncalves, J.M., Erzini, K., 2010. Quantifying recreational shore angling catch and harvest in southern Portugal (north-east Atlantic Ocean): implications for conservation and integrated fisheries management. J. Fish Biol. 76, 2216-2237.

Zalba, S.M., Nebbia, A.J., Fiori, S.M., 2008. Propuesta de plan de manejo de la reserva natural de uso múltiple bahía San Blas, 1a ed. Universidad Nacional del Sur, Bahía Blanca, 147pp.

Zeller, D., Booth, S., Pauly, D., 2007. Fisheries contributions to the gross domestic product: underestimating small-scale fisheries in the Pacific. Mar. Resour. Econ. 21, 355-374.

Zhou, S., Smith, A.D., Punt, A.D., Richardson, A.J., Gibbs, M., Fulton, E.A., Pascoe, S. Bulman, C., Bayliss, P., Sainsbury, K., 2010. Ecosystem-based fishery management. PNASS 107, 9485-9489. 